\title{
ANALISIS PENGARUH TENAGA KERJA, TINGKAT UPAH, DAN PDRB TERHADAP INDEKS PEMBANGUNAN MANUSIA (IPM) DI PROVINSIS JAWA TENGAH
}

\author{
${ }^{1}$ Citra Islamiatus Izzah, ${ }^{2}$ Ignatia Martha Hendarti \\ 1,2 Fakultas Ekonomi dan Bisnis / Universitas Pembangunan Nasional "Veteran” Jawa \\ Timur \\ Alamat Email: citraislamiatus1999@gmail.com
}

\begin{abstract}
The success of a national development is not only at a high rate of economic growth, but also seen in the success of a country in the success of human development. The purpose of this study is to find out the influence of the number of labor, wage levels, and gross domestic product (GDP) on the human development index (HDI) in Central Java Province. This type of research uses explanatory research, which is a research method that is assumed to have a relationship between independent variables and dependent variables that are influenced (Herjanto, 2007:96). This research uses secondary data with a type of time series data that is quantitative during the period 2010-2019 (ten years) with the province of West Java as the object of research. The analysis model used in this study was multiple linear regression. From the results of the $F$ test showed that labor variables and GDP simultaneously have a positive and significant influence on the human development index. While the wage level simultaneously has a negative and significant influence on the human development index in Central Java Province.
\end{abstract}

Keywords: HDI, Labor, Wage Rate, GDP

\begin{abstract}
ABSTRAK
Keberhasilan suatu pembangunan nasional tidak hanya pada laju tingkat pertumbuhan ekonomi yang tinggi, namun dilihat pula pada keberhasilan suatu negara dalam keberhasilan pembangunan manusia. Tujuan dari penelitian ini yaitu untuk mengetahui pengaruh jumlah tenaga kerja, tingkat upah, dan produk domestik bruto (PDRB) terhadap indeks pembangunan manusia (IPM) di Provinsi Jawa Tengah pada. Jenis penelitian ini menggunakan eksplanatory research yaitu metode penelitian yang diasumsikan adanya hubungan antara variabel bebas (independent) dengan variabel terikan (dependent) yang dipengaruhinya (Herjanto, 2007:96). Penelitian ini menggunakan data sekunder dengan jenis data time series yang bersifat kuantitatif selama kurun waktu 2010-2019 (sepuluh tahun) dengan wilayah Provinsi Jawa Barat sebagai obyek penelitian. Model analisis yang digunakan dalam penelitian ini adalah regresi linear berganda. Dari hasil uji $F$ menunjukkan bahwa variabel tenaga kerja dan PDRB secara simultan memiliki pengaruh positif dan signifikan terhadap indeks pembangunan manusia. Sedangkan tingkat upah secara simultan memiliki pengaruh negatif dan signifikan terhadap indeks pembangunan manusia di Provinsi Jawa Tengah.
\end{abstract}

Kata Kunci : IPM, Tenaga Kerja, Tingkat Upah, PDRB 


\section{Pendahuluan}

Pembangunan merupakan suatu upaya atau proses untuk melakukan perubahan kearah yang lebih baik. Proses pembangunan meliputo berbagai perubahan diberbagai aspek sosial, politik, ekonomi, dan budaya. Oleh karena itu, pembangunan merupakan suatu syarat mutlak bagi keberlangsungan suatu negara. Komponen dasar atau nilai inti keberhasilan suatu pembangunan ekonomi, yaitu kecukupan (sustenance), jati diri (selfesteem) dan kebebasan (freedom), dimana merupakan tujuan pokok yang harus dicapai oleh setiap masyarakat (Todaro, 2000:26). Kecukupan dalam hal ini artinya kemampuan masyarakat untuk memenuhi kebutuhan hidup dasar seperti sandang, pangan, papan, kesehatan dan keamanan yang sangat dibutuhkan oleh masyarakat dalam menjalankan kehidupannya.

Makna pembangunan ekonomi yaitu suatu upaya yang dilakukan untuk mengunrangi kemiskinan, menanggulangi ketimpangan pendapatan, dan penydiaan lapangan pekerjaan. Salah satu indikator penting dalam pembangunan ekonomi yaitu peningkatan kualitas sumber daya manusia. Menurut The united Nations Development Programme (UNDP) menyebutkan bahwa pembangunan manusia dilakukan sebagai suatu proses perluasan pilihan manusia dalam meningkatkan kesempatan masyarakat untuk dapat memperoleh pendidikan, pelayanan kesehatan, penghasilan dan pekerjaan. Salah satu indikator yang digunakan untuk melihat perkembangan kualitas sumber daya manusia yaitu Indeks Pembangunna Manusia (IPM).

Keberhasilan pembangunan nasional tidak hanya dilihat dari laju tingkat pertumbuhan ekonomi yang tinggi, tetapi hal yang paling penting adalah keberhasilan pembangunan manusia. Indeks Pembangunan Manusia (IPM) adalah suatu proses untuk memperbesar pilihan yang ada bagi manusia. Menurut Badan Pusat Statistik (BPS), dalam mengukur kualiatas hidup pembangunan manusia maka ukuran yang dapat digunakan adalah IPM dari suatu wilayah atau daerah tersebut. IPM menjelaskan bagaimana suatu penduduk di suatu wilayah dapat mengakses hasil pembangunan dalam memperoleh pendapatan, kesehatan dan pendidikan untuk menentukan peringkat atau level pembangunan suatu wilayah atau negara.

Konsep IPM pertama kali dikenalkan oleh UNP melalui Human Development Report tahun 1996, yang kemudia terus berlanjut setiap tahunnya. Dalam publikasinya pembangunan manusia didefinisikan sebagai "a process of enlarging people's choice" atau suatu proses yang meningkatkan aspek kehidupan masyarakat. Aspek kehidupan ini dilihat dari panjang usia dan hidup sehat, pendidikan yang memadai, dan standart hidup yang layak. Secara spesifik UNDP menetapkan empat elemen utama dalam pembangunan manusia, yaitu produktivitas, pemerataan, keberlanjutan, dan pemberdayaan.

Indeks Pembangunan Manusia (IPM) merupakan suatu ukuran yang digunakan untuk mengetahui kualita hidup pembangunan manusia. Terdapat beberapa komponen dalam indeks pembangunan manusia (IPM) yaitu capaian sehat dan umur panjang yang mewakili bidang kesehatan, partipasi sekolah dan lamanya bersekolah, dan angka melek huruf mewakili dalam bidang pendidikan, dan daya konsumsi masyarakat terhadap kebutuhan pokok yang dilihat sesuai dengan pengeluaran perkapita.

Ada tiga indikator yang terdapat pada IPM yaitu lama hidup yang diukur dengan angka harapan hidup ketika lahir, pendidikan yang dapat diukur dengan rata-rata lama sekolah, dan angka melek huruf. Menurut United Nations Developmet Program (UNDP) salah satu indikator yang digunakan untuk mengukur tingkat keberhasilan pembangunan manusia yaitu, terdapat angka dari IPM yang berkisar antara 0-1, dimana semakin mendekati angka 1 maka pembangunan manusia pada suatu negara atau daerah akan semakin membaik. 


\section{Gambar 1}

Indeks Pembangunan Manusia Provinsi Jawa Tengah 2010-2019

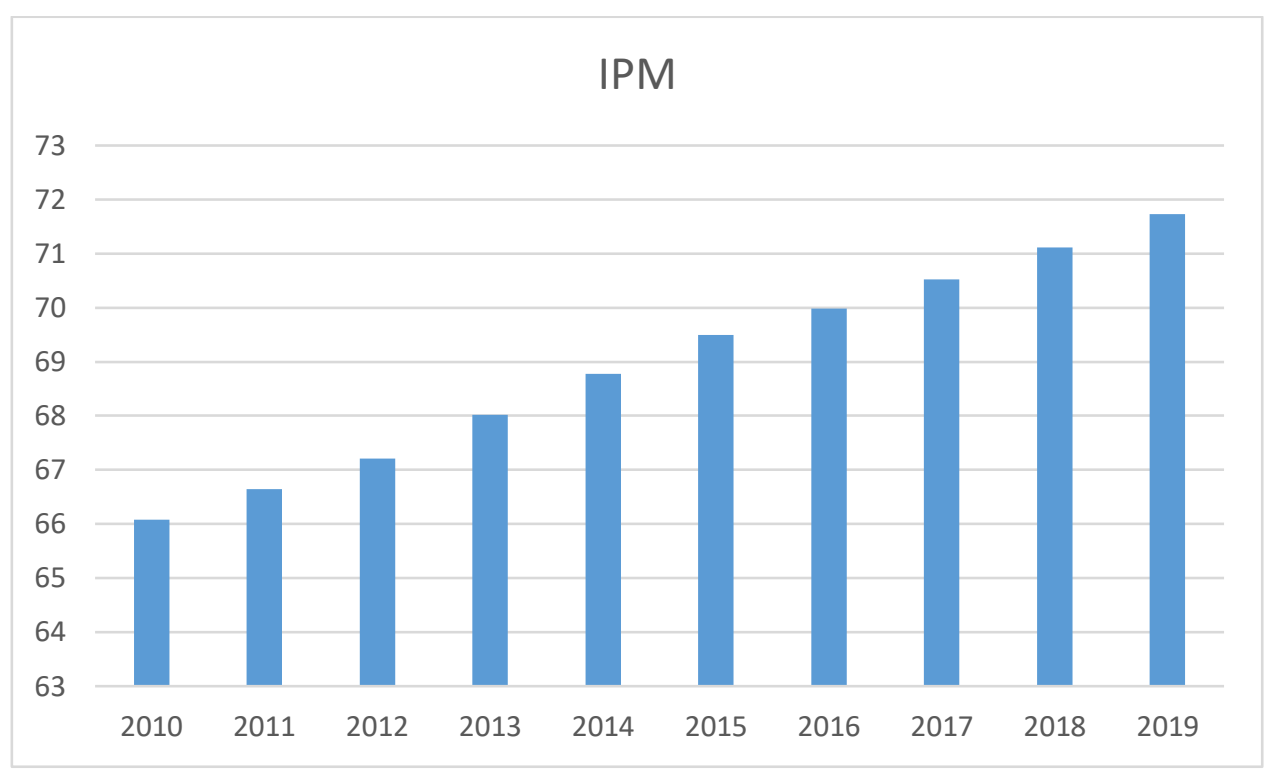

Sumber : BPS (diolah)

Dari gambar di atas dapat kita lihat bahwa setiap tahunnya Indeks Pembangunan Manusia (IPM) di Provinsi Jawa Tengah mengalami tren kenaikan terus menerus. Kenaikan peningkatan Ipm menunjukkan bahwa adanya tingkat kesejahteraan yang juga meningkat. Terlihat pada tahun 2010 IPM Provinsi Jawa Tengah 66,08\% kemudian terus meningkat hingga tahun 2019 menjadi $71,73 \%$.

Penelitian ini ingin mengetahui pengaruh tenaga kerja, tingkat upah, dan produk domestik regional bruto (PDRB) terhadap indeks pembangunan manusia (IPM) di Provinsi Jawa Tengah.

\section{Kajian Teoritis}

Indeks Pembangunan Manusia (IPM)

Menurut Badan Pusat Statistik (BPS), dalam mengukur kualitas hidup pembangunan manusia maka ukuran yang dapat digunakan adalah Indeks Pembangunan Manusia (IPM) dari suatu wilayah. Di dalam IPM terdapat beberapa komponen seperti kesehatan, partisipasi sekolah, dan lamanya bersekolah, angka melek huruf mewakili dari bidang pendidikan, serta daya konsumsi masyarakat terhadap sejumlah kebutuhan pokok yang dilihat sesuai dengan pengeluaran perkapita. Dengan adanya investasi pada setiap komponen tersebut, tentunya akan meningkatkan kualitas sumber daya manusia. Semakin tinggi tingkat pendidikan seseorang maka akan mempengaruhi kualitas orang tersebut, terutama dalam hal pekerjaan. Ketika kualitas sesorang pekerja bagus maka akan memperoleh hasil yang lebih baik. Sehingga mereka akan mendapat gaji atau upah yang besar ketika dapat memperoleh hasil yang banyak (Mulyadi, 2003).

Tenaga Kerja

Tenaga kerja adalah penduduk yang memasuki usia kerja 15-64 tahun yang sudah bekerja maupun yang sedang mencari kerja. Menurut UU No.13 Tahun 2003 Bab I pasal 1 
ayat 2 menyebutkan bahwa tenaga kerja adalah orang yang mampu menghasilkan barang dan jasa untuk memenuhi kebutuhan hidupnya sendiri maupun masyarkat. Tenaga kerja merupakan faktor penggerak paling penting dalam proses produksi untuk menghasilakan barang dan jasa akhir. Setiap kegiatan produksi diperlukan jumlah tenaga kerja yang memadai dan disesuaikan dengan jumlah yang dibutuhkan.

Salah satu masalah mendasar yang dihadapi Indonesia adalah masalah pengangguran dimana pemerintah dengan berbagai upaya yang dilakukan untuk mengurangi tingkat pengangguran. Upaya yang ditempuh oleh pemerintah dalam persolan pengangguran dari masa ke masa dilakukan dengan berbagai pendekatan pembangunan yang bertumbu pada pertumbuhan ekonomi (production contered development). Namun pada kenyataannya masalah ketenagakerjaan di Indonesia masih banyak yang belum dapat diatasi oleh pemerintah.

Produk Domestik Bruto (PDRB)

Indikator yang sering digunakan untuk menilai kinerja perekonomian suatu negara adalah Produk Domestik Bruto (PDB), sedangkan indikator untuk mengetahui kinerja ekonomi suatu wilayah atau daerah dalam suatu negara tertentu yaitu Produk Domestik Regional Bruto (PDRB) yang merupakan salah satu indikator penting untuk mengetahui kondisi ekonomi suatu wilayah atau daerah dalam satu periode tertentu, atau merupakan jurmlah barang dan jasa yang dihasilkan oleh seluruh unit ekonomi pada suatu daerah. Baik berdasarkan harga berlaku atau atas dasar harga konstan.

PDRB atas harga berlaku merupakan nilai tambah barang dan jasa yang dihitung menggunakan harga pada tahun berjalan. PDRB atas harga berlaku digunakan untuk mengetahui kemampuan sumber daya ekonomi, pergeseran, da struktur ekonomi suatu daerah, sedangkan PDRB atas harga konstan menunjukkan nilai tambah barang dan jasa tersebut yang dihitung menggunakan harga yang berlaku pada satu tahun tertentu sebagai tahun dasar. PDRB atas dasar harga konstas digunakan untuk mengetahui pertumbuhan ekonomi secara riil dari tahun ke tahun atau pertumbuhan ekonomi yang tidak dipengaruhi oleh faktor harga (Bank Indonesia, 2016).

Upah

Menurut David Ricardo dalam Teori Upah Wajar (alami), tingkat upah digunakan sebagai balas jasa bagi tenaga kerja merupakan harga yang diperlukan untuk mempertahankan dan melanjutkan kehidupan para tenaga kerja. Ricardo juga menyatakan bahwa perbaikan upah hanya ditentukan oleh perbutan dan perilaku tenaga kerja dan pembentukan uoah sebaiknya diserahkan kepada persaingan pasar bebas. Di pasar akan terdapat upah menurut harga pasar dimana upah yang terjadi di pasar dan oleh permintaan dan penawaran upah harga berubah disekitar upah menurut kodrat. Oleh para ahli ekonomi modern, upah kodrat dijadikan sebagai batas minimum dari upah kerja.

Upah merupakan salah satu biaya produksi yang sangat berpengaruh terhadap keuangan perushaan. Biasanya perubahan upah akah cepat memberikan respon terhadap tingkat produksi perushaan, sehingga biasanya perusahaan memilih untuk mengurangi jumlah produksinya. Dengan meningkatnya upah tenaga kerja maka akan membuat kebutuhan akan tenaga kerja berkurang, sehingga akan berpengaruh pada penurunan jumlah tenaga kerja yang dibutuhkan akibat skala produksi. Apabila terjadi kenaikan upah beberapa perusahaan lebih memilih untuk menggunakan teknologi untuk proses produksinya dan menggantikan kebutuhan tenaga kerja dengan kebutuhan barang modal seperti mesin (Sumarsono, 2009). 


\section{Metodologi Penelitian}

Jenis Penelitian yang digunakan adalah eksplanatory research yaitu metode penelitian yang diasumsikan adanya hubungan antara variabel bebas (independent) dengan variabel terikan (dependent) yang dipengaruhinya (Herjanto, 2007:96). Dalam penelitian ini menjelaskan hubungan antara Tenaga Kerja, UMP, dan PDRB terhadap IPM. Lokasi penelitian ini dilakukan di Provinsi Jawa Tengah dengan periode waktu penelitian 2010-2019.

Penelitian ini menggunakan data sekunder dengan jenis data time series yang bersifat kuantitatif selama kurun waktu 2010-2019 (sepuluh tahun) dengan wilayah Provinsi Jawa Barat sebagai obyek penelitian. Sumber data yang digunakan dalam penelitian ini bersumber dari Badan Pusat Statistik (BPS) dan berdasarkan penelitian terdahulu.

Model analisis yang digunakan dalam penelitian ini adalah regresi linear berganda. Regresi linier berganda digunakan untuk mengetahui besar pengauh perubahan dari suatu variabel independen terhadap variabel dependen.

Untuk memudahkan dalam menganalisis data maka penelitian ini menggunakan bantuan software SPSS 13. Dengan estimasi ekonometrika sebagai berikut:

$$
\text { IPM }=\beta_{0}+\beta_{1} T K+\beta_{2} \text { UMP }+\beta_{3} \text { PDRB }+\varepsilon
$$

Keterangan:

$$
\begin{array}{ll}
\text { IPM } & =\text { Indeks Pembangunan Manusia } \\
\text { TK } & =\text { Penyerapan Tenaga Kerja } \\
\text { UMP } & =\text { Upah Minimum Provinsi } \\
\text { PDRB } & =\text { Produk Domestik Regional Bruto } \\
\beta_{0} & =\text { Konstanta } \\
\beta_{1,2,3} & =\text { Koefisien Regresi (paramater yang diestimasi) } \\
\varepsilon & =\text { Error term (variabel gangguan) }
\end{array}
$$

Regresi linier berganda harus memenuhi asumsi yang ditetapakn agar menghasilkan koefisien yang ditetapkan melalui uji yang meliputi uji normalitas, multikolinearitas, heteroskedatisitas, dan autokorelasi. Disamping uji asumsi klasik juga dilakukan uji signifikan. Uji signifikan ini dilakukan untuk mengukur ketepatan fungsi regresi sampel dalam menarik nilai aktualnya, yang dapat diukur dari goodness of fitnya. Secara statistik dapat diukur melalui koefisien determinannya $\left(R^{2}\right)$, nilai signifikan simultan $(F)$, dan uji parsial (t).

\section{Hasil dan Pembahasan}

Berdasarkan uji asumsi klasik, diketahui bahwa model regresi telah bersifat BLUE (Best Linier Unbiased Estimation). Berarti bahwa model regresi tidak bias, konsisten dalam hasil atas pengujian, dan tepat dalam estimasi. Selanjutnya, pengujian diteruskan dengan uji $F$ untuk melihat pengaruh seluruh variabel bebas terhadap variabel terikat. Dari hasil olah data dengan menggunakan SPSS 13, diperoleh nilai F statistik sebesae 96,967 dengan $\mathrm{F}$ tabel 4,76 pada nilai tingkat signifikan sebesar $5 \%$. Dapat dikatakan bahwa model penelitian yang digunakan merupakan model terbaik dan dapat digunakan untuk meramalkan pengaruh indeks pembangunan manusia (IPM) dengan tenaga kerja, tingkat upah, dan produk domestik bruto (PDRB). 


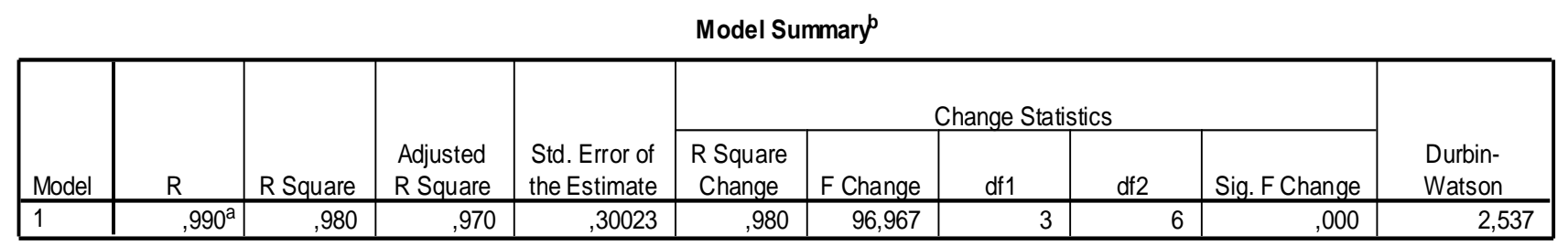

a. Predictors: (Constant), tk, ump, pdrb

b. Dependent Variable: ipm

ANOVA

\begin{tabular}{|c|c|c|c|c|c|c|}
\hline \multicolumn{2}{|c|}{ Model } & $\begin{array}{l}\text { Sum of } \\
\text { Squares }\end{array}$ & $\mathrm{df}$ & Mean Square & $\mathrm{F}$ & Sig. \\
\hline \multirow[t]{3}{*}{1} & Regression & 26,221 & 3 & 8,740 & 96,967 &, $000^{\mathrm{a}}$ \\
\hline & Residual &, 541 & 6 & ,090 & & \\
\hline & Total & 26,762 & 9 & & & \\
\hline
\end{tabular}

a. Predictors: (Constant), tk, ump, pdrb

b. Dependent Variable: ipm

\begin{tabular}{|c|c|c|c|c|c|c|c|c|c|c|}
\hline \multicolumn{11}{|c|}{ Coefficients $^{\mathrm{a}}$} \\
\hline \multirow{2}{*}{\multicolumn{2}{|c|}{ Model }} & \multicolumn{2}{|c|}{$\begin{array}{c}\text { Unstandardized } \\
\text { Coefficients }\end{array}$} & \multirow{2}{*}{$\begin{array}{c}\begin{array}{c}\text { Standardized } \\
\text { Coefficients }\end{array} \\
\text { Beta } \\
\end{array}$} & \multirow[b]{2}{*}{$t$} & \multirow[b]{2}{*}{ Sig. } & \multicolumn{2}{|c|}{$95 \%$ Confidence Interval for B } & \multicolumn{2}{|c|}{ Collinearity Statistics } \\
\hline & & $\mathrm{B}$ & Std. Error & & & & Lower Bound & Upper Bound & Tolerance & VIF \\
\hline \multirow[t]{4}{*}{1} & (Constant) & 58,995 & 4,323 & & 13,647 &, 000 & 48,417 & 69,573 & & \\
\hline & pdrb & $6,29 \mathrm{E}-005$ &, 000 & ,850 & 1,637 & ,153 &, 000 &, 000 & ,012 & 80,026 \\
\hline & ump & $-1,3 \mathrm{E}-007$ & ,000 &,- 040 &,- 087 & ,934 &, 000 &, 000 & ,016 & 63,357 \\
\hline & tk & $2,62 \mathrm{E}-006$ & ,000 & 189 & 1,072 & ,325 &, 000 &, 000 & ,108 & 9,220 \\
\hline
\end{tabular}

a. Dependent Variable: ipm

Dalam penelitian ini dapat kita lihat bahwa tenaga kerja dan pendapatan domestik regional bruto (PDRB) memiliki pengaruh yang poitif dan signifikan terhadap indeks pembangunan manusia (IPM) di Provinsi Jawa Tengah. Nilai $R^{2}$ yang diperoleh adalah 0,980 yang artinya variabel tersebut dapat menjelaskan keterkaitan variabel $Y$ dengan variabel yang lain sebesar $98 \%$ sedangkan $2 \%$ sisanya dijelaskan oleh variabel lain. Selanjutnya pada uji t dengan tingkat signifikan $5 \%$ dilakukan untuk mengetahui pengaruh variabel bebas terhadap variabel terikatnya. Dari tabel coefficients persamaan regresi yang dihasilkan dari uji t yaitu:

$$
\mathrm{Y}=13,647+1,637 \mathrm{PDRB}-0,087 \mathrm{UMP}+1072 \mathrm{TK}
$$

Pengaruh Tenaga Kerja terhadap IPM

Variabel tenaga kerja memiliki nilai signifikan sebesar $0,026<0,05$. Maka $\mathrm{H}_{0}$ ditolak dan $\mathrm{H}_{\mathrm{a}}$ diterima, dengan demikian dapat disimpulkan bahwa Tenaga Kerja secara simultan memilik pengaruh positif dan signifikan terhadap IPM. Yang berarti bahwa setiap adanya peningkatan tenaga kerja maka akan menaikkan IPM Provinsi Jawa Tengah. Tingkat Pendidikan yang semakin meningkat berdampak pada pengetahuan masyarakat dan keahlian masyarakat yang meningkat sehingga meningkatkan produktivitas kerja yang tinggi. Produktivitas yang tinggi akan menghasilkan tenaga kerja dengan kualitas yang bagus dan akan memperoleh hasil produksi yang semakin banyak. Produksi dengan memperoleh hasil yang lebih banyak maka pendapatan yang diterima akan menjadi lebih besar dan konsumsi yang juga meningkat. Sehingga Indeks Pembangunan Manusia yang tinggi akan meningkatkan penyerapan tenaga kerja (Mulyadi, 2003). Artinya, semakin tinggi 
kualitas sumber daya manusia maka akan memberikan peningkatan penyerapan tenaga kerja di Provinsi Jawa Tengah.

Pengaruh Upah terhadap IPM

Variabel upah memiliki nilai signifikan sebesar 0,305 $>0,05$. Maka $\mathrm{H}_{0}$ diterima dan $\mathrm{H}_{\mathrm{a}}$ ditolak, dengan demikian dapat disimpulkan bahwa upah secara parsial memilik pengaruh negatif dan signifikan terhadap IPM. Yang berarti bahwa setiap adanya peningkatan upah maka tingkan IPM akan menurun Provinsi Jawa Tengah.

\section{Pengaruh PDRB terhadap IPM}

Variabel PDRB memiliki nilai signifikan sebesar 0,002 $<0,05$. Maka $\mathrm{H}_{0}$ ditolak dan $\mathrm{H}_{\mathrm{a}}$ diterima, dengan demikian dapat disimpulkan bahwa PDRB secara simultan memilik pengaruh positif dan signifikan terhadap IPM. Yang berarti bahwa setiap adanya peningkatan PDRB maka akan menaikkan IPM Provinsi Jawa Tengah. Hal ini dikarenakan semakin tinggi tingkat pertumbuhan PDRB di Provinsi Jawa Tengah maka akan meningkatkan kualitas hidup layak masyarakatnya sehingga akan berdampak pada kesejahteraan bagi masyarakat di Kabupaten/Kota Provinsi Jawa Tengah.

\section{Penutup}

Kesimpulan

Berdasarkan uraian hasil penelitian dan pembahasan, dapat ditarik kesimpulan bahwa pada tingkat signifikan sebesar $5 \%$ variabel tenaga kerja dan produk domestik regional bruto (PDRB) secara simultan memiliki pengaruh yang positif dan signifikan terhadap indeks pembangunan manusia (IPM) di Provinsi Jawa Tengah. Sedangkan Tingkat Upah memiliki pengaruh negatif dan signifikan terhadap indeks pembangunan manusia (IPM) di Provinsi Jawa Tengah. Dalam penelitian ini menjelaskan bahwa keterikatan variabel independen dapat menjelaskan variabel dependen sebesar $98 \%$.

\section{Saran}

Pembangunan manusia merupakan salah satu dimensi yang prioritas dala program pemerintah. Upaya yang dilakukan dalam meningkatkan kualitas hidup manusia dilakukan melalui pembangunan manusia sebagai faktor sumber daya pembangunan. Peningkatan kualitas hidup manusia dapat dilakukan dengan cara:

1. Pemerintah harus berupaya dalam memberikan pelatihan kepada masyarakat untuk meningkatkan kemampuan atau skill yang mereka miliki agar dapat digunakan sebagai nilai tambah individu dalam melamar pekerjaan yang di inginkan, sehingga dengan cara tersebut akan meningkatkan kualitas manusia dan banyak tenaga kerja yang terserap pada suatu wilayah atau daerah.

2. Perusahaan harus mampu memberikan upah sesuai dengan tingkat kemampuan atau kualitas yang dimiliki oleh individu tersebut hal ini dapat dikualifikasikan melalui salah satu indikator pembangunan manusia yaitu pendidikan. Semakin tinggi tingkat pendidikan dan kemampuan yang dimiliki oleh seorang individu maka tingkat upah yang di dapatkan oleh individu tersebut tinggi pula. Maka dengan begitu tingkat kesejahteraan individu akan mengalami peningkatan.

3. Peran pemerintah dibutuhkan dalam meningkatkan PDRB, intervensi pemerintah dibutuhkan melalui kebijakan anggaran, ijin usaha, pengembangan UMKM, dan sebagainya untuk dapat meningkatkan perekonomian di berbagai sektor. Ekonomi 
yang meningkat akan meningkatkan kesejahteraan manusia yang secara tidak langsung akan meningkatkan indeks pembangunan manusia.

\section{Daftar Pustaka}

BPS Provinsi Jawa Tengah . https://jateng.bps.go.id/. Diakses 16 November 2020.

BPS. (2019). Indeks Pembangunan Manusia 2019. Jakarta: BPS.

Baeti Nur. (2013). PENGARUH PENGANGGURAN, PERTUMBUHAN EKONOMI, DAN PENGELUARAN PEMERINTAH TERHADAP INDEKS PEMBANGUNAN MANUSIA KABUPATEN/KOTA DI PROVINSI JAWA TENGAH TAHUN 2007-2011. Economics Development Analysis Journal 2(3)

Chalid, N., \& Yusuf, Y. (2014). PENGARUH TINGKAT KEMISKINAN, TINGKAT PENGANGGURAN, UPAH MINIMUM KABUPATEN/KOTA DAN LAJU PERRUMBUHAN EKONOMI TERHADAP INDEKS PEMBANGUNAN MANUSIA DI PROVINSI RIAU. "Jurnal Ekonomi 22(2), 1-12.

Fahmi Anisa, Khairul Amri D. (2018). PENGARUH GOOD GOVERNANCE, BELANJA FUNGSI PENDIDIKAN DAN KESEHATAN, DAN PDRB PERKAPITA TERHADAP IPM. Jurnal Manajemen Keuangan Publik 2(1)

Shafira, A. (2020). PENGARUH PDRB, UPAH MINIMUM, INFLASI, DAN IPM TERHADAP PENYERAPAN TENAGA KERJA DI PROVINSI JAWA TENGAH TAHUN 20102018 (Doctoral dissertation, Universitas Islam Indonesia).

UNDP. 2011. Human Development Report 2011. New York: Oxford University Press

Zainudin, Z. (2015). ANALISIS DAMPAK INFLASI, PDRB, DAN PERKEMBANGAN UPAH MINIMUM REGIONAL TERHADAP INDEKS PEMBANGUNAN MANUSIA DI PROVINSI ACEH. Jurnal Ekonomi Manajemen dan Akuntansi (JEMSI), 1(1). 